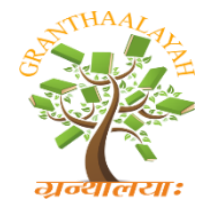

INTERNATIONAL JOURNAL OF RESEARCH GRANTHAALAYAH A knowledge Repository

Social

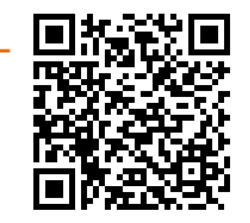

\title{
AWARENESSABOUT CLEAN INDIA PROGRAMME AMONG PROSPECTIVE TEACHERS IN TIRUNELVELI DISTRICT
}

\author{
Mr. M. Raja ${ }^{* 1}$, Mrs. S. Anitha ${ }^{2}$ \\ ${ }^{* 1}$ M.Ed. Scholar, M.E.T. College of Education, Chenbaharamanputhur, Kanyakumari district, \\ India \\ ${ }^{2}$ Assistant Professor in General Education, M.E.T. College of Education, Chenbaharamanputhur, \\ Kanyakumari district, India
}

DOI: https://doi.org/10.29121/granthaalayah.v5.i3(SE).2017.1924

\begin{abstract}
In this study the investigator made an attempt to find out the awareness about Clean India Programme of prospective teachers in Tirunelveli District with respect to their gender, locality, type of family, type of college, religion, age, parental income. Survey method was adopted for the study. Using simple random sampling technique the investigators selected a sample of 60 prospective teachers as sample foe analysis. The findings revealed that the prospective teachers did not differ in their awareness about clean India programme with respect to the gender, location of the college, type of the family, type of the college, religion, age and parental income. Thus we conclude that the prospective teachers in Tirunelveli district have no significant difference in their awareness about Clean India programme. The level of awareness about Clean India Programme was at moderate level.
\end{abstract}

Keywords: Clean India Programme; Teachers; Awareness.

Cite This Article: Mr. M. Raja, and Mrs. S. Anitha. (2017). "AWARENESSABOUT CLEAN INDIA PROGRAMME AMONG PROSPECTIVE TEACHERS IN TIRUNELVELI DISTRICT." International Journal of Research - Granthaalayah, 5(3)SE, 1-6. https://doi.org/10.29121/granthaalayah.v5.i3(SE).2017.1924.

\section{Introduction}

\section{"Cleanliness is next to Godliness"}

India is the seventh largest country in the world, is well marked from the rest of India by mountains and the sea, which gives the country a distinct geographical outlook. For Indians, conservation of environment is not a new concept. We had a long tradition of love, respect and reverence for nature. Historically, the protection of nature and wildlife formed an ardent article of faith, reflected in the daily lives of people and also enshrined myths, folklore, religion, art and 
culture. Rulers, saints and common people also respected and loved wildlife. This tradition still continues.

Development must be environmentally sound and sustainable without any constraints to quality of life. India take all these seriously and several efforts are underway. Today in India we see the seeds of such efforts in different directions in order to meet the challenges. Also efforts have been made by common people, non-governmental organisations, voluntary agencies and government as well.

At the dawn of the 21 stcentury, a powerful and complex web of interactions has contributed to unprecedented global trends in environmental degradation. These include rapid globalization, urbanization, poverty, unsustainable consumption patterns and population growth. They have served to compound the effects and intensity of the global environmental problems. Global climate change, depletion of the ozone layer, desertification, deforestation, loss of the planet's biological diversity, trans-boundary movements of hazardous wastes and chemicals are all environmental problems that touch every nation and adversely affect the lives and health of their populations. Hence the investigator tries to find out the Awareness of Swachh Bharat Mission in the cleanliness of modern India.

\section{Need and Significance of the Study}

The father of our nation Mahatma Gandhi stated that, "Sanitation is more important than independence" during his time before the independence of India. He was well aware of the bad and unclean situation of India. He emphasized clearly that the people of India has to do a lot about the cleanliness and sanitation as well as its implementation in the daily lives. However, it was not so effective and failed because of the incomplete participation of people. After many years of independence of India, a most effective campaign of cleanliness was launched to call people for their active participation and complete the mission of cleanliness.

Through this campaign the government of India solved the sanitation problems by enhancing the waste management techniques. Clean India movement is completely associated with the economic strength of the country. The Gandhi Jayanthi day is targeted in both, the launch and completion of the mission. The basic goals behind launching the Swachh Bharat Mission are to make the country with full of sanitation facilities as well as elimination of all the unhealthy practices of people in their daily routines.

Why 'Clean India Mission' is important in India?

- It is needed in India to convert the insanitary toilets into flushing toilets.

- It is necessary in order to eradicate the manual scavenging system.

- It is to implement the proper waste management through the scientific processes, hygienic disposal, reuse and recycling of the municipal solid wastes.

- It is to bring behavioural changes among Indian people regarding maintenance of personal hygiene and practice of healthy sanitation methods.

- It is to create global awareness among common public living in rural areas and link it to the public health. 
- It is to support working bodies to design, execute and operate the waste disposal systems locally.

- It is to bring private-sector participation to develop sanitary facilities in all parts of India.

- It is making India as Clean and Green India.

- It is to improve the quality of life of people in rural areas.

- It is to bring sustainable sanitation practices by motivating communities and Panchayat Raj Institutions through the awareness programmes like health education.

- It is to realise the dream of Mahatma Gandhi at least by 2020.

\section{Review of Related Literature}

Sahi (2008) conducted a study on Awareness of Environmental Pollution on a sample of 300 high school students. The main objectives were to find out whether there is any significant difference among Hindu, Christian and Muslim high school students in their environmental pollution awareness, to find out whether there is any significant difference between male and female high school students in their environmental pollution awareness. The methodology followed was survey method. The investigator used Environmental Pollution Awareness Scale by Dr.Shanthy (2008). Data were analysed by using the statistical techniques t-test and ANOVA. The findings revealed that in terms of religion of high school students it was found that about 39.39 per cent of Hindu students, 44.67 per cent of Christian students and 50 per cent Muslim students have high awareness of environmental pollution. The findings also revealed that with regard to female students develop awareness on environmental pollution due to their house keeping nature.

Sathawara (2014) conducted a study on Environmental Awareness for Clean and Green India on a sample of 150 higher secondary school students. The main objectives were, to find out the level of environmental awareness among the higher secondary school students, to find out the difference in the environmental awareness of higher secondary school students with respect to the demographic variables gender, type of management, medium of instruction. The investigator used Environmental Awareness Inventory by Pragnesh Sathawara (2014). Data were analysed by using the statistical techniques t-test and ANOVA. The findings revealed that 35.33 per cent of students having average level of environment awareness, 33 per cent of students having low level of environment awareness and 31.67 per cent of students having high level of environment awareness. The findings also revealed that there exists a significant difference in environment awareness with regard to gender, type of management, medium of instruction.

Tiwari (2014) conducted a study on Awareness of National Mission Swachh Bharat: SwachhVidyalaya in the middle school students of private and public schools on a sample of 200 middle school students. The main objective was to estimate the awareness of National Mission Swachh Bharat: SwachhVidyalaya in the middle school students of private and government school students. The investigator used standardized questionnaire. Data were analysed by using the statistical technique t-test. The findings revealed that there was no significant difference in the Awareness of a national mission Swachh Bharat: Swachh Vidyalaya in students of private and government schools. 


\section{Statement of the Problem}

This study is entitled on "AWARENESS ABOUT CLEAN INDIA PROGRAMME AMONG PROSPECTIVE TEACHERS IN TIRUNELVELI DISTRICT”.

\section{Objectives of the Study}

1) To find out the level of prospective teachers awareness about Clean India Programme.

2) To find out whether there is any difference in the awareness about Clean India Programme of prospective teachers with regard to demographic variables like gender, location of the college, type of the family, type of the college, religion, age and parental income.

\section{Hypotheses of the Study}

1) The Awareness about Clean India Programme among prospective teachers is at moderate level.

2) There is no significant difference in the awareness about Clean India Programme of prospective teachers with regard to the demographic variables like gender, location of the college, type of the family, type of the college, religion, age and parental income.

\section{Methodology}

The investigator adopted normative survey method of research to study the problem. Clean India Awareness Test is the tool developed for the investigation. The sample of the present investigation included 60 prospective teachers from various colleges of education located in Tirunelveli district. The collected data were analyzed by using statistical techniques like percentage analysis, mean, standard deviation, t-test and ANOVA.

\section{Results and Discussion}

\section{Hypothesis testing using level analysis \\ Hypothesis: 1 \\ Awareness about Clean India Programme among prospective teachers is at moderate level.}

Table 1: Data and results of Level Analysis of prospective teachers in their awareness about Clean India Programme

\begin{tabular}{|c|l|l|l|}
\hline \multicolumn{1}{|c|}{ Variables } & Groups compared & $\mathbf{N}$ & Percentage \\
\hline Clean India Programme Awareness & Low & 11 & 18.3 \\
\cline { 2 - 5 } & Medium & 37 & 61.7 \\
\cline { 2 - 5 } & High & 12 & 20.0 \\
\hline & Total & 60 & 100 \\
\hline
\end{tabular}

Table 1 showed that 18.3 percent of prospective teachers have low awareness, 61.7per cent of them have medium awareness and 20per cent of them have high awareness level about Clean India Programme. 


\section{Hypothesis testing using t-test}

\section{Hypothesis 2:}

There is no significant difference in the awareness about Clean India Programme of prospective teachers with regard to the demographic variables viz., Gender, Location of the college, Type of the family and Type of the college.

Table 2: Comparison of Awareness about Clean India Programme of prospective teachers based on the variables Gender, Location of college, Type of family and Type of college

\begin{tabular}{|c|c|c|c|c|c|c|}
\hline Variables & Groups compared & $\mathbf{N}$ & Mean & SD & t-value & Significance \\
\hline \multirow[t]{2}{*}{ Gender } & Male & 35 & 15.11 & 4.490 & \multirow[t]{2}{*}{1.646} & \multirow[t]{2}{*}{ Not significant } \\
\hline & Female & 25 & 13.24 & 4.136 & & \\
\hline \multirow[t]{2}{*}{ Location of college } & Rural & 35 & 15.11 & 4.490 & \multirow[t]{2}{*}{1.646} & \multirow[t]{2}{*}{ Not significant } \\
\hline & Urban & 25 & 13.24 & 4.136 & & \\
\hline \multirow[t]{2}{*}{ Type of the family } & Joint & 38 & 14.71 & 4.667 & \multirow[t]{2}{*}{0.869} & \multirow[t]{2}{*}{ Not significant } \\
\hline & Nuclear & 22 & 13.68 & 3.945 & & \\
\hline \multirow[t]{2}{*}{ Type of college } & Aided & 25 & 13.24 & 4.136 & \multirow[t]{2}{*}{1.646} & \multirow[t]{2}{*}{ Not significant } \\
\hline & Unaided & 35 & 15.11 & 4.490 & & \\
\hline
\end{tabular}

Table 2 showed that the obtained ' $t$ ' value of the awareness about Clean India Programme of prospective teachers in terms of their gender, location of college, type of family and type of college prospective teachers are less than table value 1.96 at 0.05 level of significance. Hence it can be inferred that the prospective teachers do not differ in their awareness about Clean India Programme with respect to the gender, location of college, type of family and type of college. Therefore, the null hypothesis2statedis accepted fully.

\section{Hypothesis testing using ANOVA}

Hypothesis 3:

There is no significant difference in the awareness about Clean India Programme of prospective teachers with regard to the demographic variables viz., Religion, Age and Parental income.

Table 3: Comparison of awareness about Clean India Programme of prospective teachers based on the variables Religion, Age and parental income

\begin{tabular}{|l|l|l|l|l|c|l|}
\hline \multicolumn{1}{|c|}{ Variables } & \multicolumn{1}{|c|}{ Sources } & $\begin{array}{c}\text { Sum of } \\
\text { Squares }\end{array}$ & $\mathbf{d f}$ & $\begin{array}{c}\text { Mean } \\
\text { Square }\end{array}$ & $\begin{array}{c}\text { F } \\
\text { value }\end{array}$ & $\begin{array}{c}\text { Level of } \\
\text { Significance }\end{array}$ \\
\hline Religion & Between group & 96.867 & 2 & 48.433 & 2.628 & Not Significant \\
\cline { 2 - 6 } & Within group & 1050.467 & 57 & 18.429 & & \\
\hline \multirow{2}{*}{ Age } & Between group & 126.509 & 2 & 63.254 & 3.532 & Not Significant \\
\cline { 2 - 5 } & Within group & 1020.825 & 57 & 17.909 & & \\
\hline \multirow{2}{*}{$\begin{array}{l}\text { Parental } \\
\text { income }\end{array}$} & Between group & 145.172 & 3 & 48.391 & 2.704 & Not Significant \\
\cline { 2 - 5 } & Within group & 1002.161 & 56 & 17.896 & & \\
\hline
\end{tabular}

Table 3 showed that the obtained ' $F$ ' value of awareness about Clean India Programme of prospective teachers in terms of their religion, age and Parental income are found to be less than table value 3.00 at 0.05 level of significance. Hence it can be inferred that the prospective 
teachers do not differ in their awareness about Clean India Programme with respect to the religion, age and parental income. Therefore the null hypotheses formed in this regard are accepted.

\section{Findings of the Study}

The Clean India Awareness among prospective teachers in general is at moderate level.

There is no significant difference in their awareness about Clean India programme among prospective teachers with respect to the gender, location of college,type of family, type of college.

\section{Conclusion}

The Clean India campaign (Swachh Bharat Abhiyan), a nice welcome step to clean and green India till 2019. As we all heard about the most famous proverb that "Cleanliness is Next to Godliness", we can surely say that clean India campaign will really bring godliness all over the country in few years if it is followed by the people of India in the effective manner. Cleanliness has been started but do not need to be ended if we really want godliness in our lives forever. Healthy country societies need its citizens to be healthy and clean in every walk of life. Making people aware is important, but more important is that this awareness is converted in to actions. As government itself has taken the initiative, will definitely motivate people and make them realize that cleanliness is not just government's responsibility. On its part government can introduce a separate awareness drive too, so that more and more people join this campaign. Ultimately, these efforts will not only force people to change their attitude of "nothing will change" but also ensures their participation too.

\section{References}

[1] Chhokar, K. (2000). Sharing concerns in Environmental Education, University News, 38(26).

[2] Ecology Center Organisation (2010). Seven misconceptions about plastic and recycling. Ecology center. Retrieved June from http://www.ecologycenter.org/ptf/misconceptions.html

[3] Erol, G. and Gezer, K. (2006). Teachers Attitudes toward Environment and Environmental Problems. International Journal of Environmental and Science Education, 1(1), 65-77.

[4] Golden, S. A. R. (2017). Recent Research In Social Science \& Humanities.

[5] Jadhav, H.V. Advanced Environmental Management, Himalaya Publishing House, 1-18.

[6] Lee, E. B. (2008). Environmental Attitudes and Information Sources among African American College Students. The Journal of Environmental Education, 40(1), 29-42.

[7] Regi, S. B., \& Golden, S. A. R. (2014). A Study On Attitude Of Employee Towards Working Environment With Special Reference To RR Pvt Ltd. Review Of Research, 2(2), 1-5.

[8] Regi, S. B., Golden, S. A. R., \& Franco, C. E. (2014). EMPLOYEE PERCEPTION TOWARDS EFFECTIVENESS OF HR PRACTICES IN PUBLIC SECTOR BANKS IN TIRUNELVELI DISTRICT. Tactful Management Research Journal, 2(6), 1-4. 